\title{
MIKS EESTIKEELSETE TRÜKISTE TSENSUUR KOLIS 1869. AASTAL RIIGA?
}

Eelmisel aastal avaldatud kirjutises „Kui Liivimaa ajakirjandust tsenseeriti Riias" (Paatsi 2014) ei suutnud ma vastata küsimusele, miks järsku viidi eestikeelsete trükiste tsensuur Liivimaa pealinna Riiga, ja mõnele teiselegi küsimusele. See samm sünnitas omajagu segadust nii eestikeelse ajakirjanduse kui ka teiste trükiste tsenseerimisel ja põhjustas hulga palvekirju jätta tsensuur siiski Tartusse. Nii teatas Trükiasjade Peavalitsus Tartu üksiktsensorile vastuseks kirjastaja Heinrich Laakmanni kirjale, et muretsemiseks Eesti Postimehe tsenseerimise pärast pole mingit põhjust (EAA, f 321, n 1, s 139, 1 21-23). Sakslastest eesti- ja lätikeelsete trükiste tsensorite asendamine õigeusulistega oli küll kindel märk vene mõju tugevdamise vajadusest, ent selgemad põhjused jäävad siingi nimetamata. Loo tagamaale heidab valgust impeeriumi siseministri Aleksander Timaševi (1818-1893) konfidentsiaalne kiri 31. augustist 1869 (nr 2484) Balti kindralkuberner Pjotr Albedinskile (1826-1883). Leidsin sellest Märt Pukitsa ärakirja Eesti Kultuuriloolisest Arhiivist (f 229, m 5:17, 11-16). Proovisin küll mitmeid kordi Läti Riiklikust Ajalooarhiivist kirja originaali leida, ent asjata, sest kuberneri ja tema kantselei fond on määratu. Timašev märgib kohe kirja algul, et tema kõrgeausus on väljendanud soovi saada teateid, mis sundis tsensuuriametkonda eesti-läti trükisõna koondama Riiga. Juba seegi on üsna hämmastav, et ettevõetud sammudest polnud keskvõim teavitanud isegi kohaliku kõrgema või$\mathrm{mu}$ esindajat Balti kindralkuberneri.
Küsimus läti-eesti trükisõna koondamisest Riiga tekkis 1868. aastal sealsele üksiktsensorile läti keelt valdava abilise leidmisega. Esitatud kandidaatidest ei vastanud keegi tsensuuriametkonna tingimustele: ta ei tohtinud olla sakslane ega luterlane. Need nõudmised vastasid valitsuse üldisele taotlusele piirata germaniseerimist Balti piirkonnas. Seejuures peeti silmas, et trükisõna on abinõu ühiskonna poliitiliseks kasvatamiseks ja nõuab suurt tähelepanu ning ettevaatlikku valitsuse järelevalvet, eriti see trükisõna, mis on mõeldud rahva alamkihtidele.

Minister kirjutab, et Balti piirkonnas ei ole asjad viimastel aastatel arenenud mitte täiesti kooskõlas valitsuse kavadega, sest kohalik trükisõna on koondunud peaaegu eranditult selle inimrühma kätte, kelle tendentslikkus on väljaspool kahtlust. Eesti-läti trükisõna teenib eranditult saksa propaganda relvana, mis viib rahvahulgad igakülgsele eraldumisele ühisest isamaast. Minister möönis, et mitte üksnes toimetajad ja kirjastajad, vaid ka läti ning eesti trükiste tsensorid olid eranditult sakslastest luterlased. See on seda sobimatum, et trükiasjade valitsuses pole kirjandusja teadussfääris üldse vene inimesi, kes oleks tuttavad läti ja eesti keelega ning seetõttu võimelised jälgima eesti ja läti trükisõna tegevust ning suundumusi. See trükisõna jääb väljapoole igasugust kontrolli ja Vene riigi huvid pole siin piisavalt kaitstud. Selle kinnituseks toob minister fakte Trükiasjade Peavalitsuse tellitud kokkuvõttest läti trükisõna kohta: eranditult luterlik, rahvakooli- 
des on peamise õppeainena esiplaanil luterlik religioon, järgneb saksa keel. Kuramaa rahvakoolides on saksa keel koguni õppekeeleks. Ka läti kirjandus põhineb saksa keelel nagu ka autorite ja kirjastajate kooliharidus. 82 raamatust ja kolmest nädalalehest, mis 1868 . aastal Liivi- ja Kuramaal välja anti, pole ükski kirjutatud vene vaimus, kuid seevastu kõnelevad kõik Saksamaast, tema õnnelikust rahvast, üksmeelselt ollakse vastu õigeusule.

Nende tõikade valgusel jõudis trükivalitsus veendumusele, et vaja on pöörata tõsist tähelepanu eesti ja läti trükisõnale, kaasata tsensuuri uusi inimesi, kes ei kuulu luterlaste ja sakslaste hulka. Riia tsensuuris ilmnenud asjaolu saigi ajendiks eesti-läti tsensuuri ümberkujundamisele. Selgus muudki. Pärnus tegeles tsenseerimisega kohalik bürgermeister J. R. Jacoby, ${ }^{1}$ kes ei osanud vene keelt ja polnud suuteline täitma valitsuse korraldusi tsensuuri asjus ning tagama korrapärast läbikäimist trükivalitsusega. Juba vene keele mittevaldamine näitas tema ühekülgset saksa vaadet. Pärnu magistraat pakkus Jacoby asemele küll telegraafikontori ülemat N. F. Amendet, ${ }^{2}$ ent ka tema ei sobinud mitmel põhjusel. Tartus tegeles eesti- ja lätikeelsete teoste tsenseerimisega üksiktsensor, kes ei osanud neid keeli. Ta juhindus üksnes Tartu ülikooli kahe saksa soost lektori otsustest. Sellise korra tõttu sai arvatavasti võimalikuks Eesti Postimehe kahe lisalehe ilmumine tsensuuriametkonna loata alates 1864 . aastast 1868 . aastani. Jelgavas (Miitavis) töötas küll läti keelt oskav tsensor, ent tema töökoormus polnud piisav. Nendes kohtades polnud kohalik tsensuur sellisel tasemel, et seda säilitada.

\footnotetext{
${ }^{1}$ Julius Roman Jacoby (1818-1916), kaupmees ja Pärnu bürgermeister (1857-1862, 1866-1877).

${ }^{2}$ Nikolai Friedrich Amende (1840-1923), kauaaegne telegraafikontori ülem Pärnus. Usutavasti ei meeldinud ka tema puhul saksa päritolu ja luteri usutunnistus.
}

Trükiasjade ametkond jõudis kokkuvõttes järeldusele, et läti ja eesti trükiste tsensuur tuleb koondada Riiga. Ka ei nõua lihtrahva ajalehed, nende kinnitatud programmid ja sisu erilist ruttu trükkimisega, et neid ei võiks tsenseerida Riias. Siseminister möönab küll mõningat kaasnevat tüli toimetustele, ent toob näiteks ajalehe Don, mis ilmub kaks korda nädalas Voronežis, kuid seda tsenseeritakse Moskvas.

Tsensuuriametkonna esialgne plaan oli küll jätta eestikeelsete trükiste tsensuur Tartusse. Hakati otsima usaldusväärseid tsensoreid Tartusse ja Riiga, sobivate isikute leidmiseks pöörduti Riia õigeusu piiskopkonna juhi Veniamini ${ }^{3}$ poole. Viimane soovitas kaht keeli oskavat isikut Riia Vaimuliku Seminari õppejõudude seast, ent ei osanud nimetada Tartusse sobivat kandidaati. Seejärel langetati otsus koondada kogu tsensuur Riiga ja üksiktsensori abilisteks kinnitada Riia Vaimuliku Seminari õppejõud Andrei Ruppert (Ruperts) ja Mihhail (Mihkel) Suigusaar ilma iseseisva õiguseta keelata või lubada midagi trükki. Tekkiv kulude kokkuhoid tsensuuri ümberkorraldamisest arvati kuni 2000 rublale aastas. Minister tunnistas, et eesti-läti trükisõna ei tohi jätta tähelepanuta, tarvitusele tuleb võtta abinõud, mis pidurdaksid võimalikku kahjulikku ühekülgset saksa mõju eesti ja läti trükisõnale.

Uuendused muutsid balti tsensuuri isikkoosseisu, vähendasid sakslaste ja luteri kiriku ühekülgset mõju ning võimaldasid valitsuse paremat järelevalvet seni ligipääsematu trükisõna üle. Tehtud muudatustega polnud rahul ajalehe Eesti Postimees väljaandja ja luterlik vaimulikkond. Heinrich Laakmanni kurtmist ei pidanud minister sedavõrd kaalukaks, et loobuda vastuvõetud ot-

${ }^{3}$ Kodanikunimega Vassili Karelin (18221874), juhtis piiskopkonda 1867-1874. Oli töötanud Saaremaal Kaarma kihelkonnas ja Kuressaares preestrina (vt lähemalt Патриарх Алексий II 1999: 267-273). 
sustest, lisaks polnud trükimaterjalide läkitamine Riiga kaugeltki nii raske, nagu Laakmann oma kirjas väitis. Seda kinnitas Eesti Postimehe ilmumine ja augusti algul esitatud loataotlus uuele eestikeelsele perioodikaväljaandele. ${ }^{4}$ Liivimaa Konsistooriumi protest ${ }^{5}$ seevastu veenis kasutusele võetud meetmete otstarbekuses, mis puudutas luterlikke teoseid. Ministrile oli luteri usu puutumatus vastuvõtmatu. Ka ei võtnud ta omaks etteheidet, et asju ei kooskõlastatud kindralkuberneriga. Kasutusele võetud meetmed olid siiski üksikkorraldused, mis puudutasid üsna piiratud ringkonna huve ega muutnud seaduses ettenähtud korda.

Tartu eestikeelsete trükiste tsensuur lõpetas töö 1869. aasta mais. Eesti Postimees (14. V, nr 20) sai viimase trükiloa Tartus 13. mail 1869, järgmisele numbrile (21. V, nr 21) andis loa (28. V) Tartu politseimeister Martin von Jannau (1810-1870). ${ }^{6}$ Ühtlasi avaldas ajaleht teate trükiste läbivaatamise lõpetamisest Tartus ja edasisest kontrollist Riias

\footnotetext{
${ }^{4}$ Raske öelda, millise väljaandega oli täpselt tegemist.

${ }^{5}$ Protest on siinkirjutajale tundmatu. Ilmselt protesteeris konsistoorium selle vastu, et vaimulikke trükiseid vaatas läbi ja neile andis trükiloa küll konsistoorium, ent lõpliku otsuse tegi siiski üldtsensuuri esindav õigeusuline Suigusaar. Sellelt pinnalt ei jäänud pahandused tulemata.

6 Eesti Postimehe ilmumiskuupäev ja tsensori luba ei klapi. Tõenäoliselt ilmus ajaleht ikka pärast tsensuuriloa saamist.
}

(„Eesti Postimehhe” teadaandmised ja kulutamised 1869). Suigusaar on andnud Eesti Postimehele (11. VI, nr 24) esmakordselt trükiloa 2. juunil 1869. Samamoodi kulgesid asjad Pärnus. Sealne ajaleht avaldas veel kohaliku tsensuuri loaga Trükiasjade Peavalitsuse teate, milles „trükmeister ja seitungi wäljaandja” Borm teatas, et kiirete tööde puhul peab tellimus nüüdsest kaks nädalat varem kohal olema („Perno Postimehhe” teadaandmised ja kulutamised 1869). Suigusaar annab Perno Postimehele (18. VI, nr 24) esmakordselt ilmumisloa 7. juunil 1869.

Siseministri kirja põhjal võib öelda, et eesti- ja lätikeelsete trükiste tsensuuri Riiga koondamise laiem eesmärk oli valitsuse soov suurendada kontrolli Liivimaa põlisrahvaste ajakirjanduse ja kirjanduse üle, vähendada saksa mõju ja vahetada välja luterlastest saksameelsed tsensorid. Kulude kokkuhoid oli siinjuures siiski teisejärguline. Kogu siseministeeriumi ja sellele alluva Trükiasjade Peavalitsuse tegevus pidi kaasa aitama vene mõju suurenemisele Läänemere kubermangudes.

Artikkel on valminud sihtfinantseeritava teema „Kirjanduse formaalsed ja informaalsed võrgustikud kultuuriloo allikate põhjal” (IUT22-2) raames.

VELLO PAATSI

\section{Kirjandus}

„Eesti Postimehhe” teadaandmised ja kulutamised 1869. - Eesti Postimees 21. V, nr 21, lk 85.

$\mathrm{P}$ a a t s i, Vello 2014. Kui Liivimaa ajakirjandust tsenseeriti Riias. - Keel ja Kirjandus, nr 4, lk 284-290.

„Perno Postimehhe” teadaandmised ja kulutamised 1869. - Perno Postimees 4. VI, nr 23, lk 9.

Патриарх Алексий II 1999. Православие в Эстонии. Москва: Церковно-научный центр „Православная энциклопедия”. 